Article

\title{
Biobased Innovation as a Fashion and Textile Design Must: A European Perspective
}

\author{
Erminia D'Itria * (D) and Chiara Colombi
}

check for updates

Citation: D'Itria, E.; Colombi, C. Biobased Innovation as a Fashion and Textile Design Must: A European Perspective. Sustainability 2022, 14 , 570. https://doi.org/10.3390/ su14010570

Academic Editors: Valentina Rognoli and Carla Langella

Received: 23 November 2021

Accepted: 30 December 2021

Published: 5 January 2022

Publisher's Note: MDPI stays neutral with regard to jurisdictional claims in published maps and institutional affiliations.

Copyright: (C) 2022 by the authors. Licensee MDPI, Basel, Switzerland. This article is an open access article distributed under the terms and conditions of the Creative Commons Attribution (CC BY) license (https:// creativecommons.org/licenses/by/ $4.0 /)$.
Design Department, Politecnico di Milano, 20123 Milan, Italy; chiara.colombi@polimi.it

* Correspondence: erminia.ditria@polimi.it

\begin{abstract}
Fashion industry investments drive the choice for textile solutions characterized by radical experimentation and a firm commitment to sustainability. In the last five years, textile innovations have been strongly related to biobased textile solutions evolving to become effectively feasible and strategic. The produced qualitative knowledge implementations consider new production patterns, innovative technical and digital know-how, and new consumption scenarios. The directions the industry is tracing may provide new opportunities for future textile development in the circular biobased economy. This paper presents a map of current European practices. It discusses the possible passage through a holistic paradigm that goes beyond the boundaries of the old productive systems to accompany the sector towards a new sustainable and transversal state. It also presents three selected best practices that return the actual context in which the phenomenon occurs. A model is presented to demonstrate how these circular processes of biobased materials production enable more process innovations which are developed through implementing the process itself: companies' search for rethinking and implementing the traditional practices or designing new ones (as determined by the doctoral research of one of the authors).
\end{abstract}

Keywords: fashion design for sustainability; circular materials; biobased textiles; textile industry transformation

\section{Introduction}

Using biobased circular fibers and materials similar to their standard comparatives is a design must. Although scientific advances have introduced viable biobased alternatives into today's linear supply chains, these materials alone do not affect the current model of textile production and its associated environmental and social impacts [1]. This is a crucial issue for the fashion industry. Today, it is one of the most wasteful consumer industries globally. In this context becomes essential to embed the circular economy concept, a framework for a more efficient, closed-loop economy, as a critical way forward in the transition to a more sustainable and less wasteful fashion industry [2]. Designers must integrate materials and design-driven strategies across supply chains rather than limit them to today's system's waste stage. Therefore, a shift in the designer's mindset must be enabled who can maximize, through their action, the sustainable potential of new biobased materials all along the chain [3].

The presented topic illustrates why it is stimulating and vital, both in theory and practice, addressing that there is no one-size-fits-all solution: circularity requires a systemic approach. A fashion product is sustainable if it results from a process that considers all the steps in its production, evaluating materials and processing, maintenance, cleaning, and disposal practices [4-8].

In materials, this holistic approach profoundly impacts all the phases of the different supply chains.

Fibers are divided into two macro groups: natural and man-made. Although natural fibers are often associated with more environmentally friendly choices, to the detriment of synthetic ones for which there is widespread skepticism, the distinction is not so simple. 
There are no fibers that are better than others, and all of them serve to clothe over eight billion individuals [9]. The pivotal issue is all in how they are produced.

It is essential to understand that the main sustainability challenges in fabric production are different for different materials and that no type of fiber is without its criticality.

It is estimated that designers can control up to $80 \%$ of a product's environmental impact through creative solutions and pathways to sustainability $[10,11]$. So, if the material is the medium through which fashion expresses itself, the advent of sustainable materials has given an additional positive attribute to the material dimension as implementers of sustainable pathways [12].

Of these many opportunities offered to fashion designers, this paper will focus on a specific dimension: the biomaterials, which with their versatility, provide new ways of thinking about traditional textile production, as well as the fashion designers' practices.

The definition of biomaterial on which the broadest consensus currently exists is the one established during the II International consensus conference on biomaterials, held in Chester (England) in 1991: "A biomaterial is defined as a material designed to interface with biological systems in order to evaluate, support or replace any tissue, organ or function of the body". It should be noted that such a limited interpretation is not generally accepted in the global scientific community. A broader understanding extends the concept of biomaterial to soluble polymers, which can be used as molecular support for biologically active substances. The term includes all synthetic (metals, ceramics, polymers, composites, ...) and natural (silk, cotton, collagen, hyaluronic acid, ...) materials.

As reported, the terminology has been adapted from the field of biomedical research, but the paper will consider an interpretation that fits the fashion industry better.

For this reason, the authors have chosen to adopt the definition proposed by Biofabricate and Fashion for Good in their last report, "Understanding "bio" material innovation" [13], which considers everything falling under the umbrella term "biomaterial". All biomaterials are biobased, but the biological component can broadly vary from less than 10 to $100 \%$.

Hence, the research focused on biobased materials understood as: "Biobased materials include everything from conventional as well as non-animal "leathers" that contain fruit or vegetable waste combined with synthetic polymers, through to a pure cotton fabric or indeed a polyester-cotton mix" [13].

In this perspective, Lee and her team included in the family of biobased materials the biofabricated materials and the biosynthetic ones.

In their prospective, Biofabricated materials considers (1) biofabricated ingredients, which only include microbially produced building blocks for both "natural" and "synthetic" polymers such as silk and nylon, as well as (2) bioassembled materials include "leathers" grown by mycelium, bacteria, or mammalian cells [13]. Meanwhile, biosynthetic materials include "the production of chemicals for "synthetic" polymers, such as precursors for nylon and polyester, obtained via catalytic conversion of biomass or bio fabricated using living microbes in fermentation processes" [13].

From these definitions, one understands the complexity associated with the dimension of biomaterials and how the simple terminology does not explicitly define their production, their life cycle, and consequently, their level of sustainability.

Therefore, when we talk about sustainability and biological terms as they apply to a product, it is essential to understand the process of each specific material through in-depth analysis. This can support in navigating through the different technological approaches, inputs, and impacts related to biobased materials.

So, it follows that it is not possible to make general assumptions about any biomaterial.

Some benefits affect the environmental impact of the production, life, and disposal cycles for new biobased materials.

The path from "harvest" to fiber is more efficient than traditional manufacturing processes. This translates into significant savings in water, energy, and carbon emissions. 
For example, the chemical industry has introduced biobased synthetic fibers in the production of which petroleum derivatives are replaced by vegetable oils, starches, and sugars. These fibers reduce the use of fossil raw materials and, consequently, $\mathrm{CO}_{2}$ emissions into the atmosphere. In addition, they have lower inertia than natural degradation processes (photodegradation activated by the ultraviolet component of sunlight, followed by biodegradation by microorganisms in the environment). Therefore, their disposal takes a much shorter time than their actual use, thus helping to combat environmental degradation and avoid situations of risk to life on Earth.

However, to the important sustainable contribution just presented, it must be added that biobased materials are not a panacea. For when it comes to raw materials, although biobased textiles can be produced from sustainably sourced raw materials or waste from other industries, they can also be made from specially planted crops. These come from intensive farming, which undermines the fertility of the land that could be used to produce food resources. Therefore, consideration must be given to where crops are grown and how they are processed and transported. Additionally, a further issue is represented by the high number of chemical fertilizers and pesticides used in agriculture and the large quantities of water that release pollution into both soil and waterways.

In addition, consumers must also consider the processing of raw materials into finished materials. Sometimes these productive practices require complex chemical processing, and in the end, the biobased fibers cannot be used alone but need to be blended with other fibers to produce the finished fabric. Often the final result of this blending is an unsustainable yarn or textile that loses its sustainable characteristic during the production phase.

It is also necessary to consider what will happen once the finished, processed, and used product reaches the end of its life. Consumers tend to consider hyper-sustainable options such as composting, biodegradability, or complete recycling of the materials when it comes to biobased materials.

However, consumers cannot just throw these items in the compost bin. Many biobased textiles are mixed with non-compostable elements such as plastics during production. The result is that many biobased materials are currently difficult to compost using existing waste management services. Additionally, in some cases, the conjunction of different factors such as humidity, temperature, or sunlight is necessary in order to activate the phenomena of composting.

The same problems are considered in recycling aspects. The chemicals and ingredients that are often added to biobased materials mean that recycling them is not likely to be easy. Even materials that may be theoretically recyclable may not be recycled in practice. In many cases, the industrial production of truly sustainable biobased products is characterized by high costs that make products used only for specialized services, for example, in the biomedical field.

However, it should be noted that in the last five years, innovative materials and partnerships have appeared in every area of the textile industry, led by the fashion industry.

These realities aim to be a "critical mass" to trigger a change in the way we produce, use, collect, and manage biobased materials as waste products.

Thanks to a growing interest and numerous R\&D initiatives, biobased materials are moving away from their role as the green but underperforming products of yesteryear. The different biobased innovation approaches in the fashion industry are evolving to gradually become feasible and strategic thanks to the interest of industry giants who are beginning to invest in the new realities that are emerging as innovators in this field.

Today, we are witnessing the birth of many of these virtuous and fruitful partnerships. In this scenario, it is relevant to mention the experience of Bolt Threads. This promising American startup has managed to scale up its project of producing a biobased leather made from mycelium, thanks to the support of a consortium formed by Adidas, Stella McCartney, Lululemon, and Kering Group (https:/ / www.dezeen.com/2020/10/08/mylo-consortiumadidas-stella-mccartney-lululemon-kering-mycelium/, accessed on 22 October 2021). 
As reported by Bof, today, we are welcoming a revolution of materials. Fashion brands are "exploring alternatives to today's standard materials, with key players focused on more sustainable substitutes that include recently rediscovered and re-engineered old favorites as well as high-tech materials that deliver on aesthetics and function" [14].

Biobased solutions on the market are proof positive that renewable and circular ingredients and systems are possible, performance-driven, and profitable. They will also be a key factor in a rapid and successful transition to a circular economy model.

Starting from the presented state of the art, this paper investigates the evolution of production practices in fashion and textile. Particular attention is paid to the directions of the design-driven transition of the fashion industry from a linear to a circular model.

This paper presents a model for "the fashion design-driven biobased innovations" in a future circular system in which productive textile processes could nurture the industry's transition to a sustainable and circular paradigm in the context of the circular bioeconomy. Section 2 presents the theoretical framework for improving the passage to a circular economy. The literature explores developing new procedures of the production system that are a suitable model related to the paper findings. They support the development and discussion of the propositions of the presented research model. Section 3 describes the research method of mapping sustainability-related production practices of European fashion companies. According to the authors' investigation, this is carried out through an iterative process to model the data. This process resulted in establishing the three design-driven approaches that inform this model. It should be noted that the authors are aware that the increase in the field of biobased materials that are affecting the circular dimension during the production chain is an issue that needs to be studied in all countries. However, according to the purpose of the study, to explore the European area the choice to focus on this specific region is related to several factors: (1) the European Commission policy prescriptions that nurture initiatives focusing on a new action plan to act circularly along the entire life cycle of products. They target how products are designed to promote circular economy processes [15]; (2) the crucial role of the Fashion and Textiles industries in Europe. On the one hand, their consumption has been designated as the fourth-highest pressure category in the EU regarding the use of primary raw materials and water and fifth for greenhouse gases. On the other hand, they are a strategic asset that plays a crucial role in the economy and social well-being in many regions of Europe. The sector includes ca. 160,000 companies (of which $99.8 \%$ are micro and small companies), employing 1.5 million people and generating a turnover of EUR 162 billion [16,17]. (3) The authors' organization's knowledge and experience, based on academic study, teaching, networks, projects, and other research and practice carried out by team members in fashion design for sustainability. Section 4 reports results and discussion about the analysis of current industry practices that embeds sustainability and circularity through a systemic approach aiming to transform the industrial material flows by investing in design and knowledge. Section 4.1 maps radical innovators who have developed new technologies or systems to produce biobased materials, allowing the rise of new materials that previously did not exist or were not considered within the fashion industry. Section 4.2 reports companies that do not operate radically but focus their work on implementing practices and systems to produce biobased materials. The goal is to optimize processes that already exist or are not considered by the fashion industry. Section 4.3 maps players that explore the dynamic between the fundamentals of the modern global fashion industry and the destructive nature of the current mainstream relationship to clothing. They aim to imagine and create through new virtuous consumption scenarios through design action. Section 5 concludes with how the presented model creates opportunities for further research, which moves towards addressing and overcoming current challenges in fully materials circularity. Here, a conceptual model, is proposed. Section 6 reports limitations and future perspectives for the research suggesting how the conceptual model can be tested in the next study phase. Finally, the practical significance for organizational members of this study and the reference to policy prescriptions derived from this analysis are highlighted. 


\section{Theoretical Framework}

A prior systematic review [18] was carried out to build the study's theoretical framework. It aimed to explore developing new procedures of the production system that can advise a suitable model related to this study's findings and subsequently inform the propositions of the designed research model. This phase collected information from Scopus, Science Direct, and Google Scholar. These databases were functional to guarantee extensive coverage of the topic. Fashion Design for sustainability is still a relatively new and crossdisciplinary area [19]. The authors included review papers, conference proceedings, and book chapters. Preliminary research suggested that the concept of circularity has gained considerable momentum in the fashion industry worldwide, substantiated by Pal et al. [20]. Coherently to that which was reported by McKinsey [14], research has significantly increased since 2017 with an evident rise in publications. As the aim was to ensure the present state-of-the-art, only the most recent papers were selected. The keywords identification proved difficult as the inquiries addressed cross-disciplinary fields where engineering, material, chemistry, and business prevailed. Moreover, the authors noticed an extensive gray area, especially studies that overlap the selected topics and focus on recycling, as confirmed by the review performed by Shirvanimoghaddam et al. [21]. As a result of this phase, nine keywords were identified and researched: Circular and Fashion and Textiles and Materials and Role or Impact or Biomaterials or Manufacturing and Processes.

A total of 1686 articles resulted from those nine keyword equations applied to titles, abstracts, and keywords for Scopus and Science Direct and to "any type" for Google Scholar.

The filtering process was also challenging, as the reference literature proved to be broad and blended among different transversal disciplines. The first step was checking titles and abstracts, firstly excluding publications unrelated to the study delineation of materials production processes in/for the fashion industry. Then, it was necessary to eliminate the duplicates. The result was 26 references (Table 1). Then, full reading was performed to define inclusion and exclusion criteria successively. The first reading round proved how almost all the papers were related to the aforementioned technical fields. The authors only included articles delivering overarching discussions on circularity and materials production, and they started codifying the reported practices. The second reading round was carried out starting from the initial findings, selecting only publications further supporting some of the patterns identified. This further selection reduced the sample to 18 publications.

An explicative flowchart of the presented literature review process is shown in Figure 1.

Table 1. Full texts final selection.

\begin{tabular}{|c|c|c|c|c|c|c|c|c|c|}
\hline Title & Type & Source & Year & 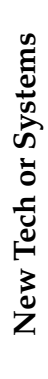 & 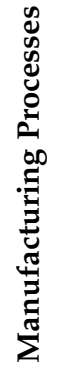 & 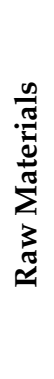 & 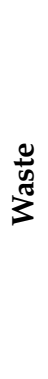 & 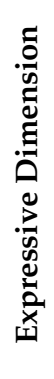 & 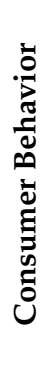 \\
\hline $\begin{array}{c}\text { Circular economy for the fashion industry: Use of waste } \\
\text { from the food industry } \\
\text { for the production of bio textiles }\end{array}$ & Article & Science Direct & 2021 & $x$ & & $x$ & $x$ & & \\
\hline $\begin{array}{l}\text { Self-healing materials: A pathway to immortal products or } \\
\qquad \begin{array}{l}\text { a risk to circular } \\
\text { economy systems }\end{array}\end{array}$ & Article & Scopus & 2021 & $x$ & & & & $x$ & $x$ \\
\hline
\end{tabular}


Table 1. Cont.

\begin{tabular}{|c|c|c|c|c|c|c|c|c|c|}
\hline Title & Type & Source & Year & 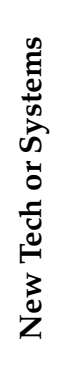 & 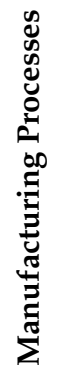 & 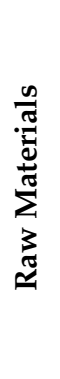 & $\begin{array}{l}\frac{0}{3} \\
\frac{\pi}{3} \\
3\end{array}$ & 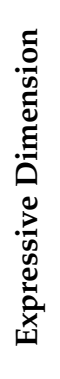 & 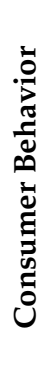 \\
\hline $\begin{array}{l}\text { Mechanical, chemical, biological: Moving towards } \\
\text { closed-loop biobased } \\
\text { recycling in a circular economy of sustainable textiles }\end{array}$ & Article & Scopus & 2021 & $\mathrm{x}$ & $\mathrm{x}$ & $\mathrm{x}$ & & & \\
\hline $\begin{array}{c}\text { Consumers' Value and Risk Perceptions of Circular } \\
\text { Fashion: Comparison between Secondhand, Upcycled, } \\
\text { and Recycled Clothing }\end{array}$ & Article & Google Scholar & 2021 & & & & & $\mathrm{x}$ & $x$ \\
\hline $\begin{array}{c}\text { Sustainable processing of food waste for production of } \\
\text { biobased products } \\
\text { for circular bioeconomy }\end{array}$ & Article & Science Direct & 2021 & $\mathrm{x}$ & & $\mathrm{x}$ & $\mathrm{x}$ & & \\
\hline $\begin{array}{c}\text { The circular economy and bioeconomy in the fashion } \\
\text { sector: Emergence of } \\
\text { a sustainability bias }\end{array}$ & Article & Scopus & 2021 & & & & & $\mathrm{x}$ & $x$ \\
\hline $\begin{array}{l}\text { Mechanical, chemical, biological: Moving towards } \\
\text { closed-loop biobased recycling in a circular economy of } \\
\text { sustainable textiles }\end{array}$ & Article & Science Direct & 2021 & $x$ & $\mathrm{x}$ & $x$ & $x$ & & \\
\hline $\begin{array}{l}\text { Close the loop: Evidence on the implementation of the } \\
\text { circular economy from the ltalian fashion industry }\end{array}$ & $\begin{array}{l}\text { Research } \\
\text { article }\end{array}$ & Google Scholar & 2021 & $\mathrm{x}$ & $\mathrm{x}$ & $\mathrm{x}$ & $\mathrm{x}$ & & \\
\hline $\begin{array}{l}\text { Special Issue on Innovative Textiles in the Era of } \\
\text { Circular Economy }\end{array}$ & Editorial & Google Scholar & 2021 & $\mathrm{x}$ & $\mathrm{x}$ & $x$ & & & \\
\hline Microbial Biotextiles for a Circular Materials Economy & Paper & Scopus & 2021 & $\mathrm{x}$ & $\mathrm{x}$ & & $\mathrm{x}$ & & \\
\hline $\begin{array}{l}\text { Towards circular fashion-transforming pulp mills } \\
\text { into hubs for textile recycling }\end{array}$ & Paper & Science Direct & 2021 & $\mathrm{x}$ & $\mathrm{x}$ & $\mathrm{x}$ & $\mathrm{x}$ & & \\
\hline $\begin{array}{c}\text { Towards Circular Economy in Fashion: Review } \\
\text { of Strategies, Barriers and Enablers }\end{array}$ & $\begin{array}{l}\text { Review } \\
\text { Paper }\end{array}$ & Google Scholar & 2021 & $\mathrm{x}$ & $\mathrm{x}$ & $\mathrm{x}$ & $\mathrm{x}$ & & \\
\hline $\begin{array}{l}\text { Sustainability and Resilience after COVID-19: A Circular } \\
\text { Premium in the Fashion Industry }\end{array}$ & Editorial & Google Scholar & 2021 & $\mathrm{x}$ & $\mathrm{x}$ & & & & $\mathrm{x}$ \\
\hline Death by waste: Fashion and textile circular economy case & Article & Scopus & 2020 & $\mathrm{x}$ & $\mathrm{x}$ & & $\mathrm{x}$ & & $\mathrm{x}$ \\
\hline $\begin{array}{l}\text { Material Designer. Boosting talent towards } \\
\text { Circular Economy }\end{array}$ & Book & Scopus & 2020 & $\mathrm{x}$ & $\mathrm{x}$ & $\mathrm{x}$ & & & \\
\hline $\begin{array}{c}\text { Toward a circular economy: Understanding consumers' } \\
\text { moral stance on corporations' and individuals' } \\
\text { responsibilities in creating a circular } \\
\text { fashion economy }\end{array}$ & Article & Scopus & 2020 & & $x$ & & & & $x$ \\
\hline $\begin{array}{l}\text { Textile recycling processes, state of the art and current } \\
\text { developments: A mini-review }\end{array}$ & $\begin{array}{l}\text { Mini- } \\
\text { review } \\
\text { Article }\end{array}$ & Scopus & 2019 & & $\mathrm{x}$ & & $\mathrm{x}$ & & \\
\hline $\begin{array}{l}\text { Transforming the biobased sector towards a circular } \\
\text { economy-What can we learn from wood cascading? }\end{array}$ & Article & Google Scholar & 2019 & & $\mathrm{x}$ & $\mathrm{x}$ & $\mathrm{x}$ & & \\
\hline
\end{tabular}




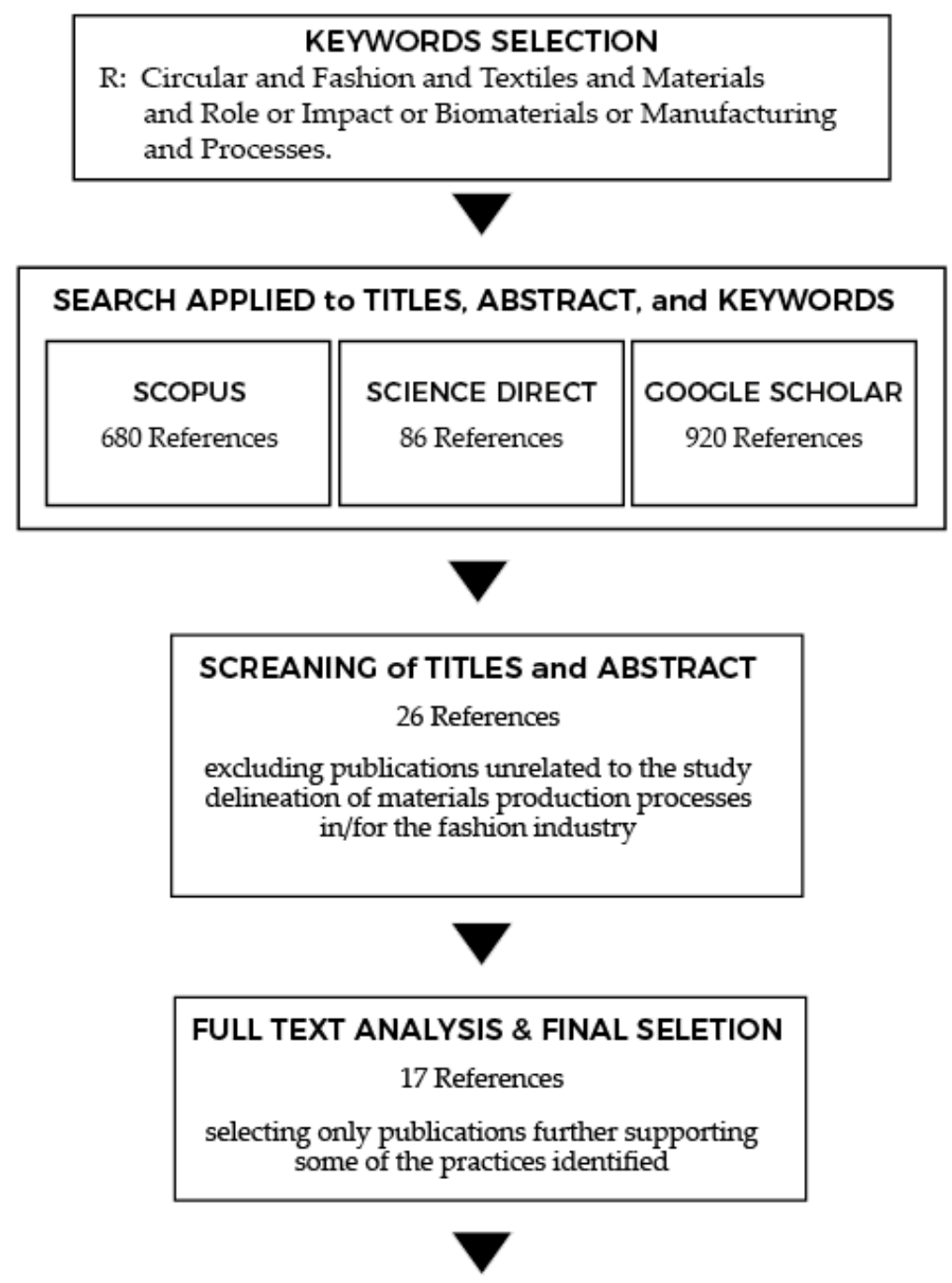

Figure 1. Theoretical framework flowchart.

The initial systematic review defined the raw frame of the study model. It informed the knowledge on how biomaterials meet the modern design criteria. It refers to aspects as renewability, low toxicity, scalability, performance, and compostability in a circular economy [22]. The first step of this theoretical investigation also took economic aspects into consideration. Even if they are not part of the focus of this study, they validate the importance of the industry of reference. Specifically, the literature addresses the benefits and untapped economic potential of efficient use of resources and waste. These materialsled practices enable dynamic capable of scaling circular business model initiatives in the fashion industry $[23,24]$.

\section{Materials and Methods}

The data processed are drawn from the knowledge reservoir produced by Fashion in Process Research Lab at Politecnico di Milano. Specifically, the information is obtained from the authors' participation in two international field studies that involved a consortium of European academic and research institutions $[25,26]$ as well as the result of the doctoral research of one of the authors [27].

An initial desk research phase was followed by applying a case study methodology to narrow a broad scope of research into easily searchable topics.

Specifically, this approach was chosen because it was deemed appropriate by the author when the analysis of existing knowledge on the subject is considered complex [28,29]. This methodology supports the researcher in dealing with such complexity by transforming 
the individual case into a functioning unit that can be investigated in its original context, thus encompassing many variables and qualities. Translating meaning from the social science, the case study methodology also bridges the gap between quantitative and qualitative methods through a mode of inductive theory generation generalization [30]. Because fashion design for circularity is still an underexplored and relatively young discipline [27], the case study methodology offers practical knowledge that, while not generalizable, allows for the development of interpretation through case studies [31].

Methodologically, the research approach consisted of four main stages to build new knowledge. The first phase of the research focused on mapping European fashion companies' sustainability-related production practices. The initial phase of desk research and literature review investigated academic and practice-based databases covering a time span of five years from 2013 to 2020. This timeframe was selected according to the data from Mckinsey [10] that reported how the patents for biobased solutions were eightfold (Table 2).

Table 2. Literature review.

\begin{tabular}{|c|c|c|c|}
\hline Typology & Database & Keywords & Selection Criteria \\
\hline Academic-based & $\begin{array}{c}\text { Scopus } \\
\text { Google Scholar }\end{array}$ & $\begin{array}{c}\text { biobased } \\
\text { sustainability } \\
\text { circularity } \\
\text { fashion } \\
\text { waste } \\
\text { textiles innovation }\end{array}$ & $\begin{array}{l}\text { Data availability } \\
\text { Level of maturity }\end{array}$ \\
\hline Policy-based & EU Platform & $\begin{array}{c}\text { sustainability } \\
\text { circularity } \\
\text { fashion } \\
\text { waste } \\
\text { textiles innovation }\end{array}$ & $\begin{array}{l}\text { Data availability } \\
\text { Level of progress }\end{array}$ \\
\hline Practice-based & $\begin{array}{c}\text { BoF.com } \\
\text { Voguebusiness.com } \\
\text { Dezeen.com }\end{array}$ & $\begin{array}{c}\text { biobased } \\
\text { sustainability } \\
\text { circularity } \\
\text { fashion } \\
\text { waste } \\
\text { textiles innovation }\end{array}$ & $\begin{array}{l}\text { Data availability } \\
\text { Level of maturity }\end{array}$ \\
\hline
\end{tabular}

Nearly 80 companies located all around Europe that have reached a mature level in their sustainable performances have been identified [26,27] (Figure 2, Table 3). These companies were characterized by a heterogeneous composition that included both fashion and textiles companies that are now working on enhancing sustainability transversally in their production. This means that they are acting not only in the design phase but also on the management and technological aspects. Coherently with the continent's industrial development trends, most of these companies were micro or SMEs [26].

Table 3. List of the mapped companies.

\begin{tabular}{|c|c|c|c|c|c|c|}
\hline Country & CODE & Sector & $\underset{\infty}{\cup}$ & $\underset{⿱ 乛}{\stackrel{\Xi}{\Xi}}$ & $\underset{\infty}{\mathbb{S}}$ & 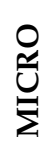 \\
\hline Austria & C1 & Materials Innovation & & & & $x$ \\
\hline Austria & $\mathrm{C} 2$ & Materials Innovation & $\mathrm{x}$ & & & \\
\hline Belgium & $\mathrm{C} 3$ & Process Innovation & & & & $x$ \\
\hline Belgium & C4 & Textile Clothing & & $\mathrm{x}$ & & \\
\hline Belgium & C5 & Textile Clothing & & & $x$ & \\
\hline Belgium & C6 & Materials Innovation, Research & & $\mathrm{x}$ & & \\
\hline Belgium & C7 & Textiles & & & & $\mathrm{x}$ \\
\hline
\end{tabular}


Table 3. Cont.

\begin{tabular}{|c|c|c|c|c|c|c|}
\hline Country & CODE & Sector & $\underset{\infty}{O}$ & 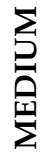 & $\sum_{\infty}^{\infty}$ & $\begin{array}{l}0 \\
\approx \\
\end{array}$ \\
\hline Czech Republic & $\mathrm{C} 8$ & Textile Clothing & & & $\mathrm{x}$ & \\
\hline Czech Republic & C9 & Materials innovation & & & $\mathrm{x}$ & \\
\hline Denmark & C10 & Material innovation & & & $\mathrm{x}$ & \\
\hline Finland & C11 & Textiles & & & & $x$ \\
\hline Finland & $\mathrm{C} 12$ & Textiles Clothing & & & $\mathrm{x}$ & \\
\hline Finland & $\mathrm{C} 13$ & Recycled material & & & & $\mathrm{x}$ \\
\hline Finland & $\mathrm{C} 14$ & Material innovation & & & & $x$ \\
\hline Finland & C15 & Recycling & & & $\mathrm{x}$ & \\
\hline Finland & C16 & Textiles & & $\mathrm{x}$ & & \\
\hline Finland & $\mathrm{C} 17$ & Textiles & & & $\mathrm{x}$ & \\
\hline France & C18 & Material and Manufacturing Innovation & & $\mathrm{x}$ & & \\
\hline Germany & C19 & Materials Innovation & & & $\mathrm{x}$ & \\
\hline Germany & $\mathrm{C} 20$ & Materials Innovation & & & & $\mathrm{x}$ \\
\hline Germany & $\mathrm{C} 21$ & Materials Innovation & & & $\mathrm{x}$ & \\
\hline Germany & $\mathrm{C} 22$ & textiles & & $x$ & & \\
\hline Greece & $\mathrm{C} 23$ & Materials Innovation & & & $x$ & \\
\hline Ireland & $\mathrm{C} 24$ & Textiles Leather Accessories & & & & $x$ \\
\hline Italy & $\mathrm{C} 25$ & Materials Innovation & & & & $x$ \\
\hline Italy & $\mathrm{C} 26$ & Materials Innovation & & & & $x$ \\
\hline Italy & $\mathrm{C} 27$ & Materials Innovation & & & & $x$ \\
\hline Italy & $\mathrm{C} 28$ & Materials Innovation & & & $x$ & \\
\hline Italy & $\mathrm{C} 29$ & Material Innovation, Recycling & & & & $x$ \\
\hline Italy & $\mathrm{C} 30$ & Material Innovation, R\&D & & $x$ & & \\
\hline Italy & C31 & Material Innovation & & & & $x$ \\
\hline Italy & $\mathrm{C} 32$ & Material Innovation, Recycling & & & & $x$ \\
\hline Italy & C33 & Textiles & & & $x$ & \\
\hline Italy & C34 & Textiles & & $\mathrm{x}$ & & \\
\hline Italy & C35 & Textiles & & $\mathrm{x}$ & & \\
\hline Italy & C36 & Textiles & & $x$ & & \\
\hline Italy & $\mathrm{C} 37$ & Textiles & & & $x$ & \\
\hline Italy & C38 & Textiles & $\mathrm{x}$ & & & \\
\hline Italy & C39 & Textiles & $\mathrm{x}$ & & & \\
\hline Italy & $\mathrm{C} 40$ & Textiles & & & $\mathrm{x}$ & \\
\hline Italy & C41 & Textiles & & & & $x$ \\
\hline Italy & $\mathrm{C} 42$ & Material Innovation, Communication & & & & $x$ \\
\hline Latvia & $\mathrm{C} 43$ & Textiles & & & & $x$ \\
\hline Luxembourg & $\mathrm{C} 44$ & Textiles Leather & & & & $x$ \\
\hline Netherlands & $\mathrm{C} 45$ & Recycling & & & $x$ & \\
\hline Netherlands & $\mathrm{C} 46$ & Materials Innovation & & & & $x$ \\
\hline Netherlands & $\mathrm{C} 47$ & Manufacturing Innovation & & & $\mathrm{x}$ & \\
\hline Netherlands & $\mathrm{C} 48$ & Material Innovation/Recycling & & $x$ & & \\
\hline Netherlands & C49 & Material Innovation & & & & $x$ \\
\hline Netherlands & C50 & Recycling & & & & $x$ \\
\hline Netherlands & C51 & Material Innovation & & & $\mathrm{x}$ & \\
\hline Netherland & C52 & Textiles & & & & \\
\hline Portugal & C53 & Materials Innovation & & & $x$ & \\
\hline Portugal & C54 & Materials Innovation & & & & $x$ \\
\hline Portugal & C55 & Materials Innovation & & & $x$ & \\
\hline Portugal & C56 & Materials Innovation & & $x$ & & \\
\hline Portugal & C57 & Materials Innovation & & $x$ & & \\
\hline Portugal & C58 & Textiles & & & & $x$ \\
\hline Spain & C59 & Materials Innovation & $x$ & & & \\
\hline Spain & $\mathrm{C} 60$ & Materials Innovation & & $x$ & & \\
\hline Sweden & C61 & Materials Innovation & & & & $x$ \\
\hline Sweden & C62 & Material Innovation & & & & $\mathrm{x}$ \\
\hline Sweden & C63 & Textiles & & & $x$ & \\
\hline
\end{tabular}


Table 3. Cont.

\begin{tabular}{|c|c|c|c|c|c|c|}
\hline Country & CODE & Sector & $\underset{\infty}{0}$ & $\sum_{\sum}^{\sum^{2}}$ & $\sum_{\infty}$ & 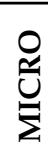 \\
\hline UK & C64 & Textiles & & & $x$ & \\
\hline UK & C65 & Material Innovation & & & $x$ & \\
\hline UK & C66 & Textiles & & & $x$ & \\
\hline UK & C67 & Textiles & & & $x$ & \\
\hline UK & C68 & Material Innovation & & & & $x$ \\
\hline UK & C69 & Material Innovation & & & & $x$ \\
\hline UK & $\mathrm{C} 70$ & Technology & & & & $x$ \\
\hline UK & C71 & Technology & & $x$ & & \\
\hline
\end{tabular}

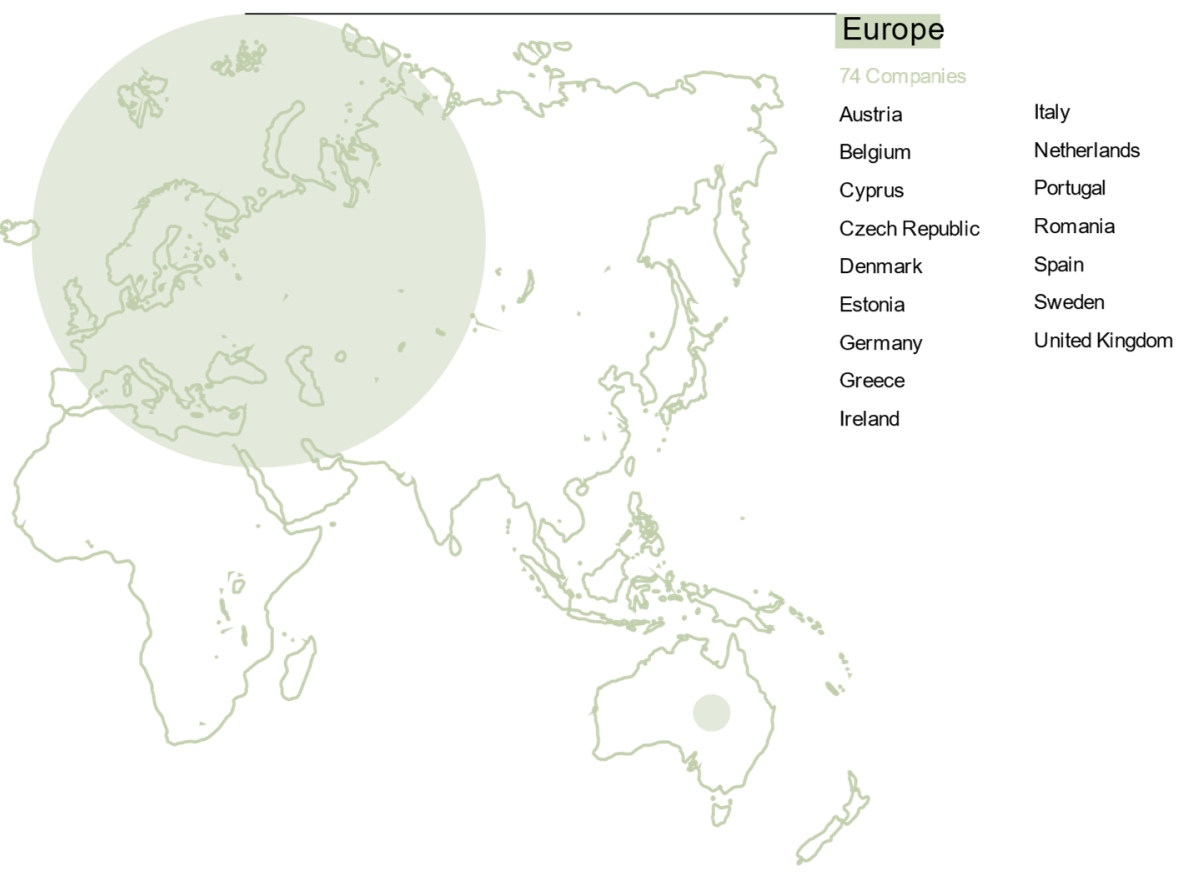

Figure 2. Companies map.

Out of the 86 companies mapped, 23 European initiatives were selected as case studies to be further investigated. The decision to focus on the European region was maturated for reasons of geographic proximity, past collaborative experiences with local relays and later became a necessity due to the limitations of the COVID-19 global pandemic.

The presented cases have distinguished themselves by the ways in which they are implementing circular practices within their systems. These companies are adopting a design thinking approach to support the design and production of new materials. They are characterized by a circular and hyper-sustainable vocation that stands as a sustainable alternative to the generation of the previous material. These new materials minimize the input of resources into the system and the loss of waste, emissions, and energy output to mitigate negative effects without compromising growth and prosperity (Table 4).

The following inquiry phase was a qualitative work that was further implemented through specific information that emerged from semi-structured qualitative interviews conducted with 15 fashion experts in both industry and research institutions (Table 5). All the cases were characterized by a strong commitment to proactively meet the surrounding environment's new needs. This was evidenced by the path that they are pursuing toward circularity. The results from this further phase supported the identification of current circular production practices in the circular fashion field. The definition of these directions 
is a first attempt to understand how a transformation to circular fashion is possible by implementing specific design-driven aspects [27].

Table 4. Research Cases.

\begin{tabular}{ccc}
\hline Name & Sector & Organization \\
\hline CS1 & Textiles & Medium textiles company \\
CS2 & Fibers & Large circular cellulose producer \\
CS3 & Materials & Large materials research center \\
CS4 & Materials & Medium manufacturing company \\
CS5 & Materials & Small manufacturing company \\
CS6 & Fibers & Small materials company \\
CS7 & Materials & Medium materials company \\
& & Large company that works on solutions \\
CS8 & Materials & and innovation for collection, reuse, and \\
& & recycling of clothing and shoes \\
CS9 & Textiles & Small textiles processing company \\
CS10 & Materials & Medium materials company \\
CS11 & Small materials company \\
CS12 & Materials & Micro materials company \\
CS13 & Materials & Small materials company \\
CS14 & Materials & Medium materials company \\
CS15 & Small textiles company \\
CS16 & Material Innovation, R\&D & Medium textiles company \\
CS17 & Textiles & Medium textiles company \\
CS18 & Textiles & Medium textiles company \\
CS19 & Textiles & Small manufacturing company \\
CS20 & Textiles & Micro textiles company \\
CS21 & Materials & Micro textiles company \\
CS22 & Textiles & Small textiles company \\
CS23 & Textiles & Micro textiles company \\
CS24 & Textiles & Small manufacturing company \\
CS25 & Textiles & Micro textiles company \\
\hline & Materials &
\end{tabular}

Table 5. Interviewee's list.

\begin{tabular}{|c|c|c|c|c|c|}
\hline \multirow{2}{*}{ CODE } & \multirow{2}{*}{ NATION } & \multirow{2}{*}{ DESCRIPTION } & \multicolumn{3}{|c|}{ TYPOLOGY } \\
\hline & & & Industry & Academia & Organization \\
\hline I1 & Austria & HEI-Art \& Design & & $x$ & \\
\hline $\mathrm{I} 2$ & Belgium & FASHION ASSOCIATION & & & $x$ \\
\hline I3 & Bulgaria & HEI—Art \& Design & & $x$ & \\
\hline \multirow[t]{2}{*}{$\mathrm{I} 4$} & Cyprus & NGO & & & $\mathrm{x}$ \\
\hline & Czech Republic & $\begin{array}{l}\text { EDUCATIONAL INITIATIVE } \\
\text { (online platform) }\end{array}$ & & $x$ & \\
\hline I5 & Denmark & NGO & & & $x$ \\
\hline I6 & Estonia & HEI—Art \& Design & & $x$ & \\
\hline I7 & Finland & HEI-Design & & $x$ & \\
\hline I8 & France & COMPANY & $x$ & & \\
\hline I9 & Germany & HEI Art \& Design & & $x$ & \\
\hline I10 & Germany & NGO & & & $x$ \\
\hline I11 & Greece & NGO & & & $\mathrm{x}$ \\
\hline I12 & Hungary & COMPANY & $x$ & & \\
\hline I13 & Ireland & FASHION ASSOCIATION & & & $x$ \\
\hline I14 & Italy & COMPANY & $x$ & & \\
\hline I15 & Italy & COMPANY & $\mathrm{x}$ & & \\
\hline I16 & Italy & HEI—Business \& Management & & $x$ & \\
\hline I17 & Italy & FASHION ASSOCIATION & & & $x$ \\
\hline $\mathrm{I} 18$ & Italy & HEI-Business \& Management & & $x$ & \\
\hline
\end{tabular}


Table 5. Cont.

\begin{tabular}{|c|c|c|c|c|c|}
\hline \multirow{2}{*}{ CODE } & \multirow{2}{*}{ NATION } & \multirow{2}{*}{ DESCRIPTION } & \multicolumn{3}{|c|}{ TYPOLOGY } \\
\hline & & & Industry & Academia & Organization \\
\hline I19 & Latvia & FASHION ASSOCIATION & & & $\mathrm{x}$ \\
\hline $\mathrm{I} 20$ & Lithuania & COMPANY & $x$ & & \\
\hline $\mathrm{I} 21$ & Luxembourg & FASHION ASSOCIATION & & & $x$ \\
\hline $\mathrm{I} 22$ & Malta & NGO & & & $\mathrm{x}$ \\
\hline $\mathrm{I} 23$ & Netherlands & NGO & & & $x$ \\
\hline $\mathrm{I} 24$ & Netherlands & FASHION ASSOCIATION & & & $\mathrm{x}$ \\
\hline $\mathrm{I} 25$ & Poland & HEI—Art \& Design & & $x$ & \\
\hline I26 & Portugal & COMPANY & $x$ & & \\
\hline $\mathrm{I} 27$ & Romania & COMPANY & $x$ & & \\
\hline $\mathrm{I} 28$ & Slovakia & FASHION ASSOCIATION & & & $x$ \\
\hline I 29 & Slovenia & NGO & & & $x$ \\
\hline $\mathrm{I} 30$ & Spain & COMPANY & $x$ & & \\
\hline I31 & Sweden & COMPANY & $x$ & & \\
\hline $\mathrm{I} 32$ & Sweden & HEI-Textiles & & $x$ & \\
\hline I33 & United Kingdom & NGO & & & $x$ \\
\hline I34 & United Kingdom & HEI-Fashion & & $x$ & \\
\hline
\end{tabular}

Furthermore, the collected information has been processed according to the Textile Exchange Benchmarking Report 2021 to measure the most relevant factors influencing the new material innovations [32]. This further step allowed us to balance the academic approach with an industry-led perspective. Specifically, the Textile Exchange bench-learning approach aims to accelerate change, drive a race to the top, and provide an opportunity for learning from collective insights and leading practices. This approach resulted as relevant to the desired aim of identifying factors influencing the new material innovations. Furthermore, the index is one of the most updated to market as it is cyclically refined through consultation with a wide range of stakeholders, including the participating companies. Additionally, the three critical areas of interest explored by the index are in line with the study's ones: (1) understanding current industry strategies, (2) targeting setting, tracking progresses and measuring impacts, and (3) implementing circularity in reducing and shifting consumption from virgin resources to reclaimed [33].

The desk research and the phase of mapping took place from March 2019 to March 2020. The semi-structured interviews were performed according to several criteria. According to a further desk research phase and experience of collaborations with the authors, people have been contacted among the most interesting theories and practices. This took place from March to June 2020.

\section{Results and Discussion}

According to what has been discussed so far, this paper aims to attempt to model current design-led practices in the field of biobased materials in the textile and fashion industries.

This section will discuss the results from the methodology on how these qualitative implementations take three main paths: new production models, innovative technical and digital know-how, and new consumption scenarios.

In light of the above, this paper presents the identified trajectories of the biomaterial contexts to determine design directions that could inspire and promote new meaningful perspectives in the field of sustainable textile and fashion design. This work aims to answer the potential pathways to new textile materials, what they are made of, and how they should be produced to create a more sustainable material world.

From the operational point of view, the research identified three macro themes in approaching biobased materials practices from a design perspective that emerged at the intersection of the investigated path (Figure 3): 
- Innovative Design;

- Bio Fabrication;

- Emotional Design.

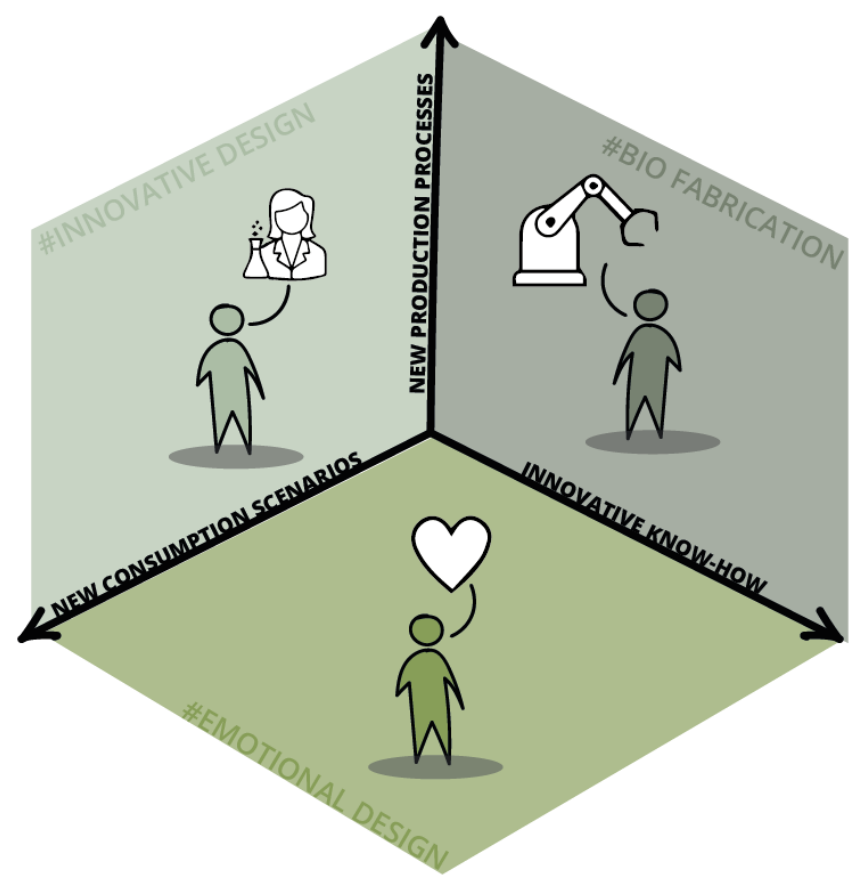

Figure 3. The design-driven biobased innovation model.

Innovative design refers to radical innovators who have developed new technologies or systems to produce biobased materials, allowing a rise in new materials that previously did not exist or were not considered within the fashion industry. Companies that fit into this category work on the production processes to design new ones with a specific focus on designing outside of the relationship between raw materials, circular economy, and the implementations allowed by advanced technologies.

In this field, there is a tendency to reconsider the manufacturing processes through trends such as digital transformation, which have allowed different realities to come across and contaminate each other, feeding back into the textile production value chain as a replacement for virgin materials.

Another important aspect of this category is the analysis and discussion of the role of waste. These companies study how to recycle any type of material from the waste of production processes to the post-consumer waste, involving third industries supply chains. The result of this is the birth of disruptive and ecological innovations that, thanks to the development of advanced technologies, allow the production of naturally produced biomaterials with high sustainability characteristics.

The majority of these innovations are based on the "Closed-Loop Supply Chain". This is a social system in which products and their components are designed, manufactured, used, and managed to circulate for as long as possible. The results of such a system are maximum usability, minimal negative environmental impact, minimal waste generation, and the most efficient use of water, energy, and other resources throughout their life cycle [27]. Examples of companies that fall into this category are Renewcell (Renewcell, Stoccolma, Sweden) [23,34], AlgiKnit (AlgaKnit, New York, New York) [35,36], Microsilk ${ }^{\mathrm{TM}}$ (Boltthreads, Emeryville, California) [37-39], Vegea (Vegea, Bergamo, Italia) [40,41], Pinatext (Ananas Anam, London, England) [42,43], Fruitleather (Fruit Leather Rotterdam, Rotterdam, Netherlands) [44,45], and Mango Materials (Mango Materials, San Francisco, California) $[46,47]$. Often, they operate through partnership with brands to maximize the sustainable performances of the final product. Examples of these practices are the collabo- 
ration between Pinatext and ACBC to realize a circular shoe or Renewcell with Levi's (Levi Strauss, San Francisco, California) to launch the circular Levi's ${ }^{\circledR} 501^{\circledR}$ (www.renewcell. com/en/levis-501-made-with-circulose-to-be-launched-in-retail-in-early-2022/, accessed on 3 January 2022).

Bio fabrication refers to companies that do not operate in a radical way but focus their work on the implementation of practices and systems for the production of biobased materials. The goal is to optimize processes that already exist or are not considered by the fashion industry. Companies that fall into this category consider production processes already in use or rediscover forgotten archaic ones. This category, as the previous one, has a specific focus on designing the relationship between raw materials and the circular economy to which it adds aspects of hyper-sustainable engineering enabled by the development of technology.

In this group, companies rethink production processes through trends such as the ecological modernization perspective that have enabled the set of processes of change and mutation on a large scale, profoundly transforming the structures and models of organization and production [48].

In the bio fabrication category, the analysis and discussion of the role of waste is also an important aspect. These companies study, improve, or convert patents that have existed for decades to recover waste from industrial production, whether from agriculture or manufacturing. The result of this is the birth of ecological processes that, thanks to systemic development, permit the production of biomaterials with sustainable characteristics conceived in a circular perspective.

Therefore, most of these biobased materials are designed and manufactured to circulate for as long as possible. Complete recyclability and compostability are inherent features in these materials that aim to achieve the most efficient use of resources throughout their life cycles. Examples of companies that fall into this category are Worn Again (Worn Again Technologies, London, England) [49], Acquafil (Aquafil SpA, Rovereto, Italy) [50], Coronet (Coronet SpA, Corsico, Italy) [51], Evo (Fulgar, Castel Goffredo, Italy) [52], Giardini (Giardini Materiali Sintetici SpA, Vigevano, Italy) [53], and Seacell (SmartFiber AG, Rudolstadt, Germany) [54]. Companies in this category often operate through responsible partnerships. These partnerships aim to boost the sustainable characteristic of the final product. An emblematic case of these practices is the collaboration carried out by Coronet to support the brand Yatay (Yatay, Corsico, Italy) in creating sneakers with a green vocation and performance.

Emotional design refers to the importance of Expressive-Sensory Characterization of Materials for transmitting the qualities and potential of materials. Companies that fit this category explore the dynamic between the fundamentals of the modern global fashion industry and the destructive nature of the current mainstream relationship to clothing. They aim to imagine and create through the design action new virtuous consumption scenarios.

There is a propensity to consider the expressive-sensory dimension of materials from a sustainability and circularity perspective in this field, since it is no longer possible to disregard these aspects and considerations in design [7]. The design must also consider product aging, accumulation of meaning over time, and deeper notions of attachment and empathy [7]. The role of materials' sensory, expressive, and emotional dimensions becomes an important area of practice.

Another important topic regards the role of garments as dependent beings. Fashion consumption has become a passive act, and consumers no longer care for the longevity of our clothing. These companies aim to build a more intimate relationship with clothes through their care. They aim to introduce a possible future for textiles by taking active approaches towards change. They also explore the application of biology in design to provoke thought and facilitate new roles and ideals for design. Examples of designers that fall into this category are Scarlett Yang [55], Kevin Eschen and Rachael Granberry [56], and Felecia Davis $[57,58]$. They are experimenting, even in a speculative manner, to prototype emotional artifacts. 
Companies that fall into the presented categories work in the innovation of production processes to enforce and increase the efficiency of traditional ones and develop new alternatives. To achieve these objectives, these companies invest in innovative technologies and a team with digital supports capable of generating value along all the supply chain stages, facilitating different connections and cross-dimensional experiences.

These enhancements of the qualitative knowledge system spread from the company to the fashion system, with new production paradigms and evolving consumption scenarios.

According to the aforementioned directions, three case studies are presented, one for each of the proposed categories. These cases are emblematic of the themes that represent approaching biobased materials practices from a design perspective. These companies/designers are proponents of studies and the development of innovative practices. They have distinguished themselves for their contribution to the field of sustainable fashion, the circular paradigm, and the transformation of the role of consumers.

\subsection{Innovative Design: Orange Fiber}

Orange Fiber was the first and is currently the only textile brand to produce a sustainable citrus-based fabric [59]. The intrinsic characteristics of the material make it silky and impalpable, allowing it to meet the fashion industry's needs of innovation and sustainability.

Thanks to their pioneering production process, the company can produce a highquality fabric that combines two pillars of Italian excellence: textiles and food.

The company's co-founder Adriana Santanocito has developed and protected her invention with an Italian patent, then extended it to the international PCT.

Orange Fiber technology is based on a process to produce spinnable cellulose from citrus fruits, such as oranges. Cellulose is extracted from citrus fruits, which come either from the waste of agricultural plantations and/or from the waste of the industrial processing of orange derivatives as for the fruit juices industries.

Cellulose can be extracted from two different sources: from the whole citrus fruit peel, which includes both albedo and flavedo, or only from the albedo.

The characteristic of this process is that cellulose is obtained by chemical extraction, performed in the absence of chlorine, which includes treatment of the raw materials obtained from citrus fruits with hydrogen peroxide under basic conditions.

Cellulose obtained by this process can be blended with cellulose obtained by different methods, for example, cellulose extracted from wood.

Therefore, the strength of this production is its ability to amortize costs and resource exploitation through the use of waste from third-party industries.

Moreover, compared to the production of natural cellulose cotton fiber, the process proposed by Orange Fiber has many economic and environmental advantages. Suffice it to say that through the classical production techniques to obtain $1 \mathrm{~kg}$ of cotton fabric, about $11,000 \mathrm{~L}$ of water are used. Of this, $45 \%$ is represented by irrigation water necessary for the development of the plant. Instead, $1 \mathrm{~kg}$ of yarn obtained with Orange Fiber technology requires about $90 \%$ less water for irrigation, therefore it has a significant positive impact compared to standard fibers. Additionally, citrus crops need fewer pesticides than cotton crops, about $1 \%$ of pesticides per $1 \mathrm{~kg}$ of Orange Fiber yarn [60].

The circular value of this material innovation is evident and also represents its impact on the market. Orange fiber initiative, therefore, represents companies that are tracing an exact direction towards circularity. Such an approach has a double-positive action simultaneously if, on the one hand, it responds to the growing demand for ecology and sustainability on the part of consumers. On the other hand, it compensates for the needs of companies in the agri-food industry facing increasing burdens and challenges to dispose of their waste correctly. 


\subsection{Bio Fabrication: Tencel}

Tencel is a type of regenerated cellulose fiber produced from wood pulp [61]. Specifically, it is a cellulose fiber precipitated from an organic solution in which no substitution of hydroxyl groups occurs, and no chemical intermediates are formed.

Starting from the 1970s, a considerable interest developed among manufacturers for this type of fiber and for the intrinsic characteristics linked to the use of specific solvents able to dissolve the cellulose pulp, directly influencing the impact of the production process.

However, it was not until the 1980s that the Courtaulds Industry (Courtaulds, Coventry, England)in the UK developed a successful engineering approach to spinning these cellulose solutions, and then in 1992, the company reached full capacity to produce, in one of their American sites, this new regenerated fiber under the commercial name "TENCEL ${ }^{\circledR}$ " (Lenzing AG, Lensing, Austria) [62].

The R\&D work carried out by Courtaulds did not remain isolated in Europe; another important company invested in the production of this type of yarn: Lenzing. Traditionally specializing in the production of viscose rayon fiber, this Austrian company created a pilot plant to start producing lyocell fiber (another name of the Tencel fiber) in 1990. Their fullscale production plant went into operation in 1997, with an annual capacity of 12,000 tons of lyocell staple fiber called Lenzing Lyocell ${ }^{\circledR}$ (Lenzing AG, Lensing, Austria). Asserting its leadership in the international market, Lenzing acquired the TENCEL ${ }^{\circledR}$ (and their plants in Mobile, Alabama, and the one in Grimsby) in early 2000. Today, Lenzing is the world's largest producer of these fibers [63].

Tencel is a cellulose fiber made by dissolving wood pulp in a solution and then processing the resulting mixture to prepare it for the drying step called spinning. The woody material is mixed with a solvent to obtain a wet mixture before spinning. The resulting product has a honey-like consistency but hardens when it is placed in a press that pushes it through small holes to form threads. These threads are then chemically treated, and the lengths of fiber are spun into yarn and woven into cloth.

From the description presented, it is clear that this is not a natural textile fiber, but an artificial fiber made in the laboratory through processes and chemicals.

Although today's growing awareness for the environment discredits the pulp, paper, and fiber industry, researchers have been working in this field since the 1960s to address environmental concerns and investigate new methods for preparing pulp solutions [64].

The result of this research work was the identification of the N-methyl morpholine-Noxide-monohydrate (NMMO-monohydrate), which has been found to be a solvent capable of directly dissolving pulp [65].

Starting from this practice, in the last few years, Lenzing perfected a closed-loop manufacturing process which means that the solvent is recycled over and over again to produce new fibers and minimize harmful waste. Lenzing Group claims a solvent recovery rate of 99\% (https:/ / www.lenzing.com/sustainability/production/resources/chemicals, accessed on 18 November 2021).

Furthermore, even if the final Tencel fiber is biodegradable, it does not decompose completely if placed in a landfill. However, recent studies have shown that if placed under the correct environmental conditions, it has a decomposition time of just four months. This is an important environmental aspect that will represent a turning point in the future of textile production: the fiber disintegration in a monitored environment [66].

The final result of the presented process is a material whose main characteristics are excellent strength, good breathability, and moisture absorption. The fiber is very soft, smooth, and shiny, with fluid drapery.

However, care must be taken in the final stages of production. In fact, if not subjected to the correct finishing procedures, the fabric can produce unsightly pilling, which ruins its peculiar characteristics of softness and shine. On the other hand, finishing operations can reduce the characteristics of breathability and moisture absorption.

The Lenzing case explores the circularity of this material both in its production process, which is certified as non-polluting, and the transparency and traceability of its supply chain 
reported by the company through all the different stages. This company is a representative example of how focusing its work on implementing practices and systems for the production of biobased materials can optimize existing processes by focusing on the relationship between raw materials and the circular economy through hyper-sustainable engineering enabled by the development of technology.

\subsection{Emotional Design: Biogarmentry}

The biogarmentry by Roya Aghighi is a transdisciplinary collaboration of synthetic biology, material science, and design as a way to open up possibilities for the future of fashion [25]. The project is designed to address the dramatically increasing environmental impact of textile waste and air pollution. The project uses the fields of synthetic biology and design as a way to open up possibilities for the future of fashion, as well as to explore what place design should have in the human relationship with living things [67].

This project consists of several interventions aimed at creating a biodegradable living tissue capable of photosynthesis. Produced in the laboratory in collaboration with AMPEL Lab and Botany Lab, both at the University of British Columbia, the material is one of the first tests of the possibility of survival of photosynthetic living cells on natural fabrics such as different types of cellulose and protein-based fibers.

Specifically, Biogarmentry is composed of a union of a particular type of unicellular green algae (Chlamydomonas reinhardtii) and is a mix of natural fibers spun together with nano polymers capable of autonomously initiating chlorophyll photosynthesis.

The result is a completely natural and biodegradable fabric. This material has the inherent characteristics of being compostable, living, and most importantly, acting as the material can purify the air through photosynthesis.

As discussed, the innovative material explores the human relationship with living things as the life cycle of fabric directly depends on how it is cared for. This project challenges the current consumer relationship with clothing. Naturally, users are guided through their experience by unique care instructions that aim to help the user keep their bio garment alive, encouraging a relationship with it, emotional attachment, and prompting a change in perception of the garment itself and its care. This material brings agency to textiles.

This is consistent with studies showing that one of the most effective ways to eliminate some of the impacts of the current fast-fashion model is to encourage consumers to care for their clothes, enhancing the sustainability of garments through longevity and attachment [68].

The Biogarmentry case is emblematic of how disruptive approaches to circularity can happen by making fabrics alive. Users will develop an emotional attachment to their garments that can help maximize usage. Biogarmentry is tracing a path to ultimately actively impact the traditional purchase, use, and disposal patterns for buying, care, and compost.

\section{Conclusions}

This paper discussed the framework of biobased material dimension in a circular fashion and reported innovators, in the three identified categories, presenting cases from the seed development to the scaling up of bio fabricated materials.

Companies who engage in the biobased materials field are now meeting different challenges in the fact that many new biomaterials, regardless of their origin and production, undergo further processing or blending with other materials during the production chain. These practices can deeply influence the circular dimension of the material itself, damaging its ability to be recycled and therefore be positively returned to the production system.

These radical new material innovations are also constrained by the limitations imposed by research and development times and the difficulties associated with obtaining grants or funding. Material experimentations to move from runways to high-volume production 
require time and the right conjunction of factors: research, technologies, systems, but also tastes, languages, and cultures.

With this in mind, biobased materials are proving to be complex. The industry has to very clearly communicate factors such as traceability, knowing where the material comes from; transparency, knowing the biological component if and in what quantity it is present in the material, and address the recycling challenge: the possibility-expressed in percentage - of recycling the product or not.

This illustrates the point that the circular challenges facing the fashion industry are diverse, all-important, and are deeply influenced by the size and speed of the industry itself. The fashion industry has thrived following quick patterns of change. Every season, designers propose the newest collections on runways around the world, and the fashion industry completely transforms to adapt to the latest trends. These trends trickle down from the runways to the stores, and as a result many consumers buy back all their wardrobes, disposing of their old clothes. Additionally, with fast-fashion brands, this pattern of change becomes even faster according to their schedule, capable of producing up to 52 micro seasons in one year [69].

The answers to these challenges are not simple, but the many new ideas and projects combined with detailed analysis and understanding can support the industry's transition to a sustainable and circular paradigm.

\section{Study Limitations and Future Research}

The presented study has some limitations that the authors wish to address. The first limitation is related to the field of investigation. The choice to focus only on the European area appeared to be a logical one, given that the studies that nourished this work have their foundations in this continent. The mapping of the cases, confirmed by the interviews, reveals how the different realities have or are strongly developing a high level of awareness about sustainability issues and a willingness to improve efforts and actions. In this context, the result has been based on a mature sector, as the fashion industrial system in Europe is [26]. This mature market presents existing companies, products, and relatively consolidated customers. Despite a flow of SMEs that enter the market, innovation takes place slowly. While this mature market can provide stability, companies face several challenges and drawbacks in experimenting with innovations and moving towards circularity. This aspect emerged mainly from the interviews where several interviewees underlined how, compared to overseas competitors, there is still a gap in terms of research, development, and investment.

Moreover, the study faced the necessity of adapting research and its methodology during COVID-19. Compulsory social distancing practices lead the research, originally being conducted face-to-face, to be transferred online during the pandemic. The virus has also had an effect on the willingness of companies to be involved in research projects. As emerged from this study, companies expressed the need to focus on their own internal systems and those adjacent to them to limit the damage caused by the spread of the virus and the consequent worldwide lockdown.

The results should be assumed in this framework.

Future research should extend the knowledge by further investigating proposed directions to become strategically effective considering the guidelines drawn by the growing number of companies investing in this field. Their work is encouraging, even if it must be considered that biological innovation in fashion materials is still a young field. Most of the companies we find in the market today are start-ups that were born in the last decade.

However, this should not be understood as an absolute limitation. In fact, it is precisely these young but dynamic companies that will be able to demonstrate, as in part they are already doing, that they are the most suitable for survival. In fact, their dynamism will allow them to adapt to events, such as the COVID-19 emergency now or the climate one in the next few years, as well as to the rapid changes dictated by the market. 
According to the presented scenario, the proposed findings establish a framework for enabling circular processes in a materials-driven fashion system, where each cycle informs the other in the production of the final item, catering to the properties of the different biobased materials productive processes (Figure 4).

Each intervention in the fashion supply chain aims to disrupt the current production model that requires high volumes of virgin materials to be introduced to replace the ones already processed [70]. Therefore, new value chains are not considered today. The model suggests adapting processes according to the properties of the presented materials-and their corresponding supply chain steps-in the context of the circular bioeconomy, so to enable high-value uses of these biobased materials (Figure 5).

For example, materials and processes related to the emotional design category, will affect the use and disposal stages enabling care for the item and guarantee, through their biocharacteristics, a harmless impact at their disposal.

Alternatively, the model may be used to maximize the presented biobased textiles processes' sustainable vocation. As shown in Figure 6, each inner circle represents the joint use of these materials combined with sustainable design strategies such as design for longevity (physical and emotional), design for recyclability, and design for low / zero waste. These combined actions could generate new lifecycles; such a framework could inform further research.

For example, the combination of design for emotional longevity and materials of the emotional design category could enable a positive perpetual cycle related to create meaningful items resulting in a design that lasts [71].

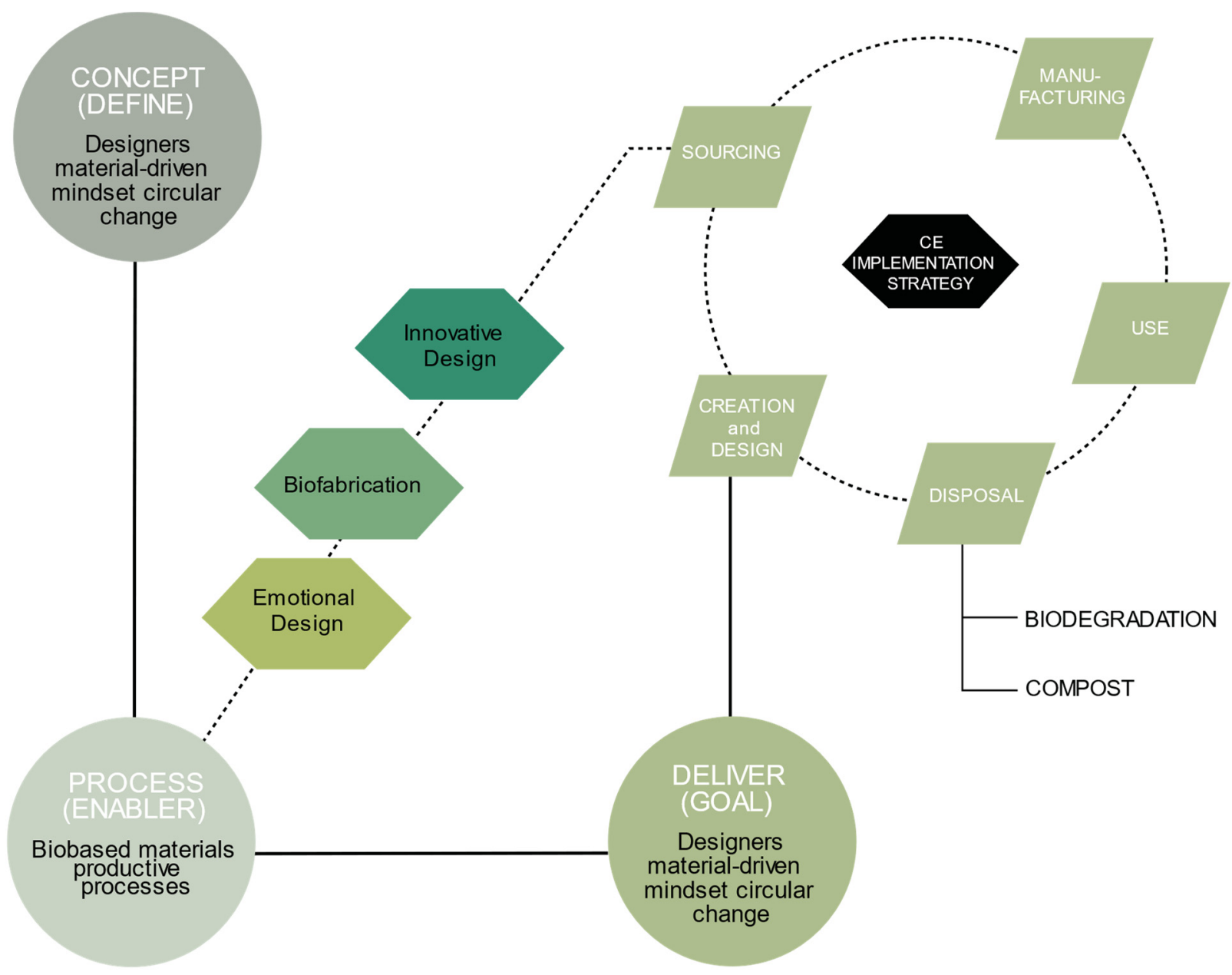

Figure 4. The design-driven biobased system conceptual model. 


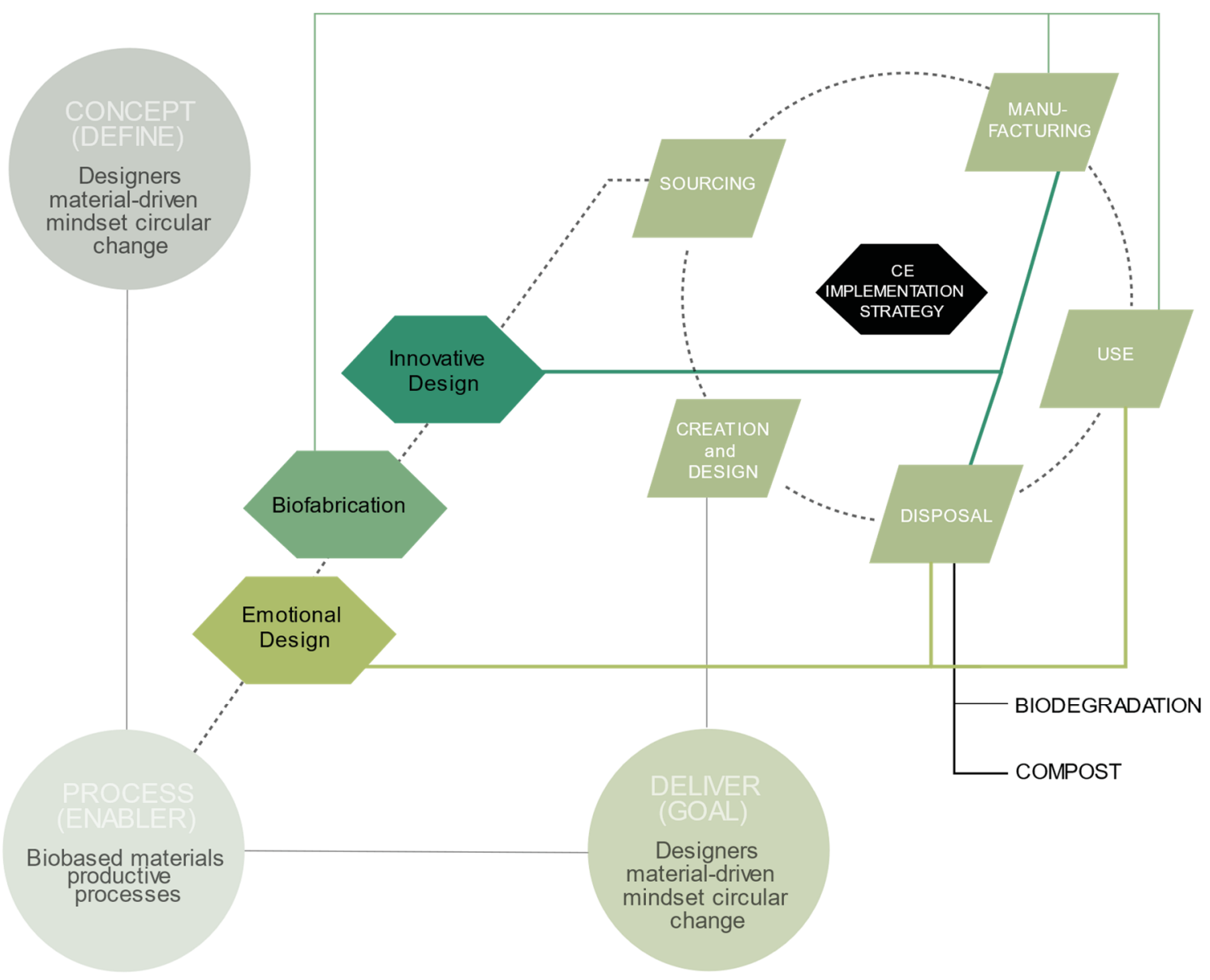

Figure 5. The design-driven biobased system conceptual model—the corresponding supply chain steps.

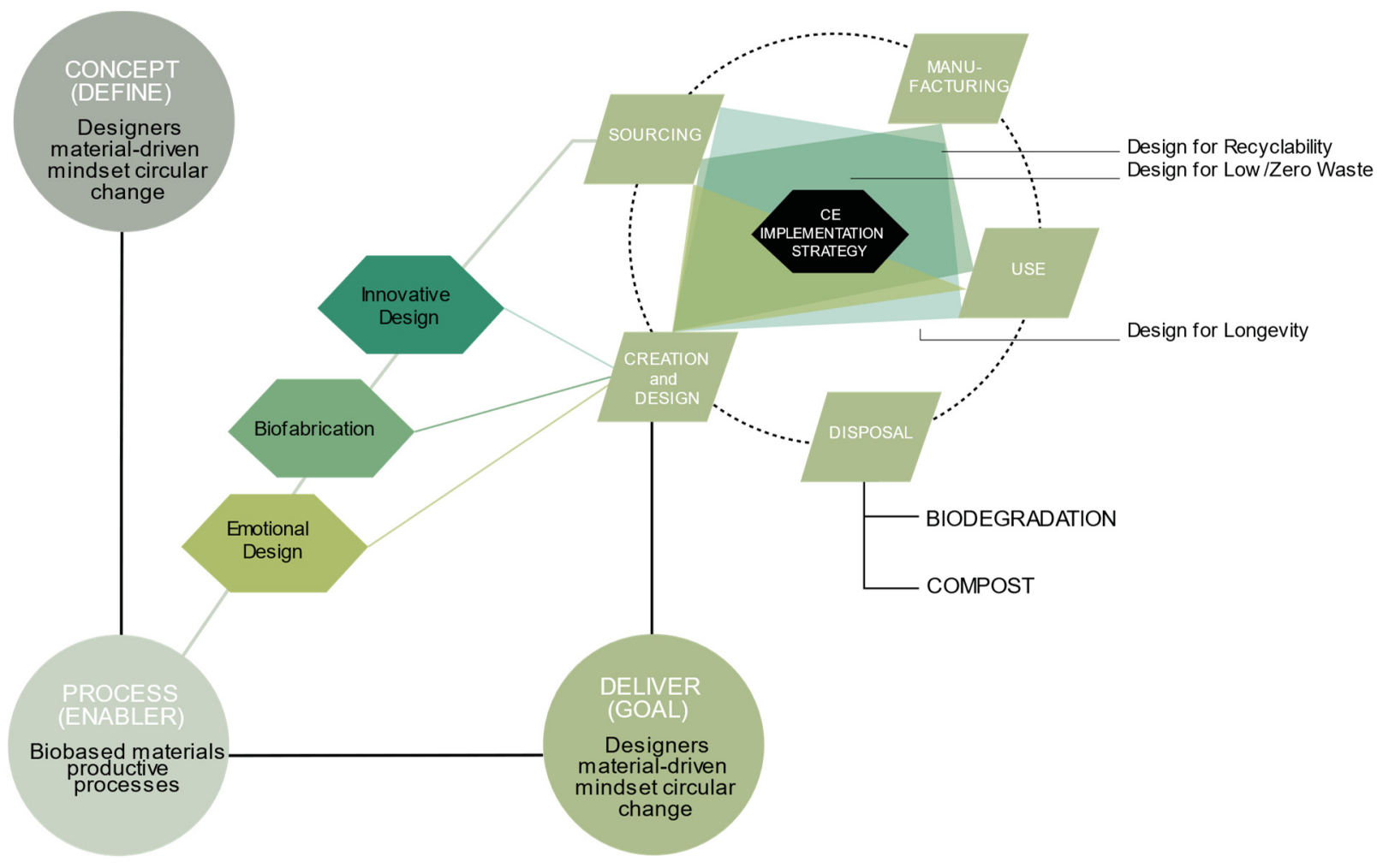

Figure 6. The design-driven biobased system conceptual model—sustainable design strategies combinations. 
In light of the foregoing, future developments in this work-informed by the data emerging from the presented research-could have practical significance for organization, such as those involved in this study, coherently with the current European policy prescriptions [72-74]. EU Commission is now implementing strategies for applying the new sustainable product framework. The EU framework will develop eco-design requirements to ensure that textile products are fit for circularity; improve the business environment by supporting the product-as-service models, circular materials, and production processes and international cooperation for increased transparency, as well as provide guidance for separate textile waste collection to boost innovation in the sorting, reuse, and recycling of textiles.

From the presented study, three possible strategies emerge that derive from the analysis and fit in the presented EU framework:

- Industrial synergies implementation. The aim is to implement industrial synergies through new product processes to close the loop. We are moving towards an evolution of the concept of waste, of the fashion product, to eliminate the old negative meaning. As advocated by the theories of circular economy, the goal is to transform the exhausted material into new raw material for other industrial processes or to be returned to the biosphere.

- Novel approaches and disruptive technologies for a sustainable transition. The aim is to challenge the dominant productive model in fashion through innovative knowhow. This could lead to imagine new processes that draw a radical, regenerative, and positive approach in driving companies to reshape the materials production dimension.

- The emotional and relational dimension of biomaterials. The aim is to explore the emotional, relational dimension of biobased materials through a new consumer scenario that can create dynamics of affective interaction. In this context, we consider the material as a vector to maximize the sustainable properties of the fashion product.

To conclude, biobased materials are a prolific field of research that is expected to continue to evolve and contribute to the quest to make fashion more sustainable and responsible.

\begin{abstract}
Author Contributions: The paper is the result of common research and findings. Nevertheless, Sections 1-6 was edited by E.D., Sections $4.1-4.3$ was edited by C.C. The methodology presented is the result of research studies and projects undertaken in recent years by the Fashion in Process Research Lab., part of the Design Department at Politecnico di Milano. All authors have read and agreed to the published version of the manuscript.
\end{abstract}

Funding: This research received no external funding.

Institutional Review Board Statement: Not applicable.

Informed Consent Statement: Not applicable.

Conflicts of Interest: The authors declare no conflict of interest.

\title{
References
}

1. Ribul, M. RegenerativeTextiles: A Framework for FutureMaterials Circularity in the TextileValue Chain. Sustainability 2021, 13, 13910. [CrossRef]

2. Brydges, T. Closing the loop on take, make, waste: Investigating circular economy practices in the Swedish fashion industry. J. Clean. Prod. 2021, 293, 126245. [CrossRef]

3. Dan, M.C.; Østergaard, T. Circular Fashion: The New Roles of Designers in Organizations Transitioning to a Circular Economy. Des. J. 2021, 24, 1001-1021. [CrossRef]

4. Kulakova, O.; Kostiuchenko, O.; Tymoshenko, O. Fashion Industry in the Context of Sustainable Development: Eco-Products, Conscious Consumption and Management. Socio-Cult. Manag. J. 2021, 4, 126-142. [CrossRef]

5. Palm, C.; Cornell, S.E.; Häyhä, T. Making Resilient Decisions for Sustainable Circularity of Fashion. Circ. Econ. Sustain. 2021, 1, 651-670. [CrossRef]

6. Tortora, M.; Tortora, G. Innovative Circular Business Models: A Case from the Italian Fashion Industry. In Sustainable Energy Investment: Technical, Market and Policy Innovations to Address Risk; InTech Open: London, UK, 2021; Volume 67. 
7. Chapman, J. Prospect, seed and activate: Advancing design for sustainability in fashion. In Routledge Handbook of Sustainability and Fashion; Fletcher, K., Tham, M., Eds.; Routledge: New York, NY, USA, 2014; pp. 74-81.

8. Fletcher, K.; Grose, L.; Hawken, P. Fashion and Sustainability: Design for Change; Laurence King: London, UK, 2012; ISBN 9781856697545.

9. United States Census Bureau (2020), Stats for Stories: World Population Day: July 11, 2020. Available online: https://www. census.gov/newsroom/stories/world-population-day.html (accessed on 6 December 2020).

10. Thackara, J. In the Bubble; MIT Press: Cambridge, MA, USA, 2005.

11. Eu Science Hub. The Ecodesign of Energy-Related Products (ErP). Available online: https://ec.europa.eu/jrc/en/research-topic/ sustainable-product-policy (accessed on 21 September 2021).

12. Richetti, M. Neomateriali Nell'economia Circolare. Moda. Ediz. A Colori; Edizioni Ambiente: Milano, Italy, 2017.

13. Understanding 'Bio' Material Innovations. A Primer for the Fashion Industry. Available online: https://reports.fashionforgood com/wp-content/uploads/2020/12/Understanding-Bio-Material-Innovations-Report.pdf (accessed on 21 September 2021).

14. Bof-Mckinsey, State of Fashion 2020. Available online: https://www.mckinsey.com/ \{\}/media/McKinsey/Industries/Retail/ Our $\% 20$ Insights /The $\% 20$ state $\% 20$ of $\% 20$ fashion $\% 202020 \% 20$ Navigating\%20uncertainty /The-State-of-Fashion-2020-final.ashx (accessed on 21 September 2021).

15. EC. The European Green Deal. Available online: https://ec.europa.eu/info/strategy/priorities-2019-2024/uropean-green-deal_it (accessed on 3 December 2021).

16. EC. Roadmp for the Sustainable Textiles Strategy 2020. Available online: http://www.interregeurope.eu/smartwaste/news/ news-article/13229/roadmap-of-the-eu-strategy-for-sustainable-textiles / (accessed on 4 December 2021).

17. EURETEXT. Textiles in Europe-Key Figures 2020. Available online: https:// euratex.eu/wp-content/uploads/EURATEX-FactsKey-Figures-2020-LQ.pdf (accessed on 4 December 2021).

18. Tranfield, D.; Denyer, D.; Smart, P. Towards a Methodology for Developing Evidence-Informed Management Knowledge byMeans of Systematic Review. Br. J. Manag. 2003, 2, 207-222. [CrossRef]

19. Fashion Design for Sustainability in Higher Education in Europe: Benchmarking Report. Available online: https://220a1b7d-a8 7a-4b80-b86f-3aa12062310a.filesusr.com/ugd/ed0694_72992639b4eb48899f6ee3b52ba392cf.pdf (accessed on 4 September 2021).

20. Pal, R.; Shen, B.; Sandberg, E. Circular fashion supply chain management: Exploring impediments and prescribing future research agenda. J. Fash. Mark. Manag. Int. J. 2019, 23, 298-307. [CrossRef]

21. Shirvanimoghaddam, K.; Motamed, B.; Ramakrishna, S.; Naebe, M. Death by waste: Fashion and textile circular economy case. Sci. Total Environ. 2020, 718, 137317. [CrossRef] [PubMed]

22. Schiros, T.N.; Antrobus, R.; Farias, D.; Chiu, Y.T.; Joseph, C.T.; Esdaille, S.; Sanchiricco, G.K.; Miquelon, G.; An, D.; Russell, S.T.; et al. Microbial biotextiles for a circular materials economy. bioRxiv 2021. [CrossRef]

23. Hultberg, E.; Pal, R. Lessons on business model scalability for circular economy in the fashion retail value chain: Towards a conceptual model. Sustain. Prod. Consum. 2021, 28, 686-698. [CrossRef]

24. Todeschini, B.V.; Cortimiglia, M.N.; Callegaro-de-Menezes, D.; Ghezzi, A. Innovative and sustainable business models in the fashion industry: Entrepreneurial drivers, opportunities, and challenges. Bus. Horiz. 2017, 60, 759-770. [CrossRef]

25. Education and Research-THE BENCHMARKING REPORT. Available online: https://www.fashionseeds.org/project-reports (accessed on 21 October 2021).

26. European Commission, Directorate-General for Internal Market, Industry, Entrepreneurship and SMEs, Support Report Mapping Sustainable Fashion Opportunities for SMES, Publications Office. 2019. Available online: https://data.europa.eu/doi/10.2873/ 694021 (accessed on 21 October 2021).

27. D'Itria, E. Driving Sustainability in Fashion through Design: Experimenting with the Role of Design in the Development of a Circular Fashion Supply Chain Model. Ph.D. Thesis, Politecnico di Milano, Milano, Italy, 2022.

28. Yin, R. Case Study Research: Design and Methods, 4th ed.; Sage Publications: Beverly Hills, CA, USA, 2008.

29. Yin, R.K. Case Study Research, Design and Methods, 3rd ed.; Sage Publications: Beverly Hills, CA, USA, 2003.

30. Johansson, R. On Case Study Methodology. Open House Int. 2007, 32, 48-54. [CrossRef]

31. Nixon, N.W.; Blakley, J. Fashion thinking: Towards an actionable methodology. Fashion Pract. 2012, 4, 153-175. [CrossRef]

32. Fletcher, K.; Grose, L. Fashion E Sustainability; Hachette: London, UK, 2012.

33. Textile Exchange Preferred Fibers Benchmarking Report 2021. Available online: https://textileexchange.org/textile-exchangepreferred-fiber-and-materials-market-report-2021/\#: \{\}:text=According $\% 20$ to $\% 20 \mathrm{a} \% 20$ new $\% 20$ Textile,materials $\% 20$ grew $\% 20$ significantly\%20in \%202020.\&text=The \%20results\%20show $\% 20$ that $\% 20$ between,from $\% 2013.7 \% 20$ to $\% 2014.7 \% 20$ percent (accessed on 10 December 2021)

34. Renewcell. Available online: https://www.renewcell.com/en/ (accessed on 10 December 2021).

35. Quijano, L.; Speight, R.; Payne, A. Future fashion, biotechnology and the living world: Microbial cell factories and forming new 'oddkins'. Continuum 2021, 35, 1-17. [CrossRef]

36. AlgiKnit. Available online: https:/ / www.algiknit.com/ (accessed on 10 December 2021)

37. MicrosilkTM. Available online: https://boltthreads.com/technology/microsilk/ (accessed on 10 December 2021).

38. Earley, R.; Worn Again: Rethinking Recycled Textiles 2005-2009. Funders Project Report Summary. 2011. Available online: www.academia.edu/38311773/PROJECT_REPORT._Worn_Again_Rethinking_Recycled_Textiles_2005_2009_(accessed on 10 December 2021). 
39. Numata, K. How to define and study structural proteins as biopolymer materials. Polym. J. 2020, 52, 1043-1056. [CrossRef]

40. Vegea. Available online: https://www.vegeacompany.com/ (accessed on 10 December 2021).

41. Cioffi, E.; Capece, S.; Pacifico, S.; Buono, M. Design and Science for the Valorisation of Residues and By-products of the Wine Industry. In International Conference on Applied Human Factors and Ergonomics; Springer: Cham, Switzerland, 2021 ; pp. $35-43$.

42. Pinatext. Available online: https://www.ananas-anam.com/ (accessed on 10 December 2021).

43. Meyer, M.; Dietrich, S.; Schulz, H.; Mondschein, A. Comparison of the Technical Performance of Leather, Artificial Leather, and Trendy Alternatives. Coatings 2021, 11, 226. [CrossRef]

44. Fruit Leather Rotterdam. Available online: https:/ / fruitleather.nl/ (accessed on 10 December 2021).

45. $\mathrm{Wu}, \mathrm{Q}$. Fashion for sustainability: Analysis of the application of sustainability concept in fashion accessories design. In 3rd International Virtual Conference on Educational Research and Innovation: CIVINEDU 2019; REDINE (Red de Investigación e Innovación Educativa): Madrid, Spain, 2019; pp. 303-307.

46. Pieja, A.; Schauer-Gimenez, A.; Oakenfull, A.; Morse, M. Biorenewables at Mango Materials. Industrial Biorenewables: A Practical Viewpoint; Wiley: Hoboken, NJ, USA, 2016; pp. 371-395.

47. Mango Materials. Available online: https://www.mangomaterials.com/ (accessed on 10 December 2021).

48. Zhu, Q.; Sarkis, J.; Lai, K.H. Green supply chain management innovation diffusion and its relationship to organizational improvement: An ecological modernization perspective. J. Eng. Technol. Manag. JET-M 2012, 29, 168-185. [CrossRef]

49. WornAgain Technologies. Available online: https://wornagain.co.uk/ (accessed on 10 December 2021).

50. Aquafil. Available online: https://www.aquafil.com/it/ (accessed on 11 December 2021).

51. Maranesi, C.; De Giovanni, P. Modern circular economy: Corporate strategy, supply chain, and industrial symbiosis. Sustainability 2020, 12, 9383. [CrossRef]

52. Coronet Tessuti Bio. Available online: https:// coronetspa.it/ (accessed on 11 December 2021).

53. Evo by Fulgar. Available online: https:/ / www.fulgar.com/ita/prodotti/evo (accessed on 11 December 2021).

54. Giardini. Available online: https://www.giardini.com/ (accessed on 11 December 2021).

55. Yimin, Q.I.N. Structure and properties of Seacell fiber. J. Text. Res. 2007, 11, 136-138.

56. Scarlett Yang. Available online: https://www.dezeen.com/2020/08/28/scarlett-yang-biomaterial-dress-central-saint-martinsfashion-design/ (accessed on 11 December 2021).

57. Researchers Invent Shape-Changing Textiles Powered Only by Body Heat. Available online: https://cse.umn.edu/college/news/ research-brief-researchers-invent-shape-changing-textiles-powered-only-body-heat (accessed on 11 December 2021).

58. Kumar, B.; Thakur, S. (Eds.) Textiles for Advanced Applications; BoD-Books on Demand: Norderstedt, Germany, 2017.

59. Orange Fiber. Available online: https:/ / orangefiber.it/ (accessed on 21 September 2021).

60. Santanocito, A.; Vismara, E. Production of Textile from Citrus Fruit. US Patent No. US9771435B2, 26 September 2017.

61. Tencel. Available online: https:/ / www.tencel.com/ (accessed on 21 September 2021).

62. Chen, J. Synthetic Textile Fibers. In Textiles and Fashion: Materials, Design and Technology; Elsevier Inc.: Amsterdam, The Netherlands, 2015; pp. 79-95. [CrossRef]

63. Lenzing. Chemicals. Available online: https://www.lenzing.com/sustainability/production/resources/chemicals (accessed on 21 September 2021).

64. Mbe, P.W. Lyocell: The production process and market development. In Regenerated Cellulose Fibres; Woodings, C., Ed.; Woodhead Publishing Limited: Cambridge, UK, 2001; pp. 62-87.

65. McCorsley, C.C., III. Process for Shaped Cellulose Article Prepared from a Solution Containing Cellulose Dissolved in a Tertiary amine N-Oxide Solvent. US Patent 4,246,221, 20 January 1981.

66. Lenzing. Sustainability. Available online: https://sustainability.lenzing.com/fileadmin/template/pdf/WOW_2017 _Biodegradability_of_wood-based_cellulose_fibers_Plasser_Rahbaran.pdf (accessed on 21 September 2021).

67. Block, I.; Biogarmentry Clothes Can Photosynthesise Like Plants. Dezeen. 2021. Available online: https://www.dezeen.com/20 19/10/02/biogarmentry-roya-aghighi-living-clothes-photosynthesis/ (accessed on 25 May 2021).

68. Niinimäki, K.; Armstrong, C. From pleasure in use to preservation of meaningful memories: A closer look at the sustainability of clothing via longevity and attachment. Int. J. Fash. Des. Technol. Educ. 2013, 6, 190-199. [CrossRef]

69. Edelkoort, L. Anti_Fashion, A Manifesto for The Next Decade; Trend Union: Paris, France, 2016.

70. Ellen MacArthur Foundation, New Textiles Economy Report, 2017 Edition. Available online: https: / www.ellenmacarthurfoundation. org/assets/downloads/publications/A-New-Textiles-Economy_Full-Report.pdf (accessed on 15 December 2021).

71. Chapman, J. Meaningful Stuff: Design That Lasts; MIT Press: Cambridge, MA, USA, 2021.

72. European Commission. A new Circular Economy Action Plan, COM (2020) 98; European Commission: Brussels, Belgium, 2020.

73. European Commission. Roadmap for EU Strategy for Textiles; European Commission: Brussels, Belgium, 2021.

74. European Environment Agency. Textiles in Europe's Circular Economy, Briefing; European Environment Agency: Copenhagen, Denmark, 2019. 